\title{
IMPACT OF THE ROAST LEVEL ON CHEMICAL COMPOSITION OF COFFEE FROM COLOMBIA
}

\author{
Ilze Laukalēja\#, Zanda Krūma, and Ingmars Cinkmanis \\ Faculty of Food Technology, Latvia University of Life Sciences and Technologies, 22 Rīgas Str., Jelgava, LV-3004, LATVIA \\ \# Corresponding author, ilze.laukaleja@ gmail.com
}

Communicated by Inga Ciproviča

\begin{abstract}
During the roasting process, a cascade of chemical reactions occur, from which non-volatile compounds degrade and form new compounds with potential aroma attributes. Considering that the roasting process significantly influences the biologically active compound concentration and some unwanted compound formation, such as acrylamide, it is crucial to understand the roasting process from both positive and negative aspects. The aim of this study was to evaluate the chemical composition changes in different roast level coffee samples from Colombia. The moisture, $\mathrm{pH}, \mathrm{ac}-$ rylamide, total phenolic, and flavonoid content, and the volatile compound profile were analysed for coffee samples roasted at three different roast levels (light, medium, dark). The results showed a decrease of total phenolic and flavonoid concentration with increased roast level. Acrylamide concentration reached the highest peak in the medium roasted and the lowest in dark roasted coffee. With increasing roast level, the volatile organic acid concentration decreased, while furan and phenol compound concentration increased in the dark roasted coffee. Dark roasted coffee had the lowest acrylamide and organic acid concentration, and the highest $\mathrm{pH}$ in brew, which would be more suitable for coffee consumers with a sensitive stomach.
\end{abstract}

Keywords: roasting process, phenolic compounds, acrylamide, volatile profile, organic acids.

\section{INTRODUCTION}

The wide range of biologically active compounds in coffee has been linked to beneficial effects on human health. Moderate daily coffee consumption is associated with a reduced risk of cardiovascular diseases, metabolic disorders, various neurological disorders (including Alzhemer's and Parkison's diseases), and cancer types (Poole et al., 2017; Lee et al., 2019). Phenolic compounds are one of the main biologically active compound groups found in plant-based products, including coffee. Phenolic acids such as chlorogenic, caffeic, gallic acid have a higher concentration in coffee beans. Epicatechin, quercetin, kaempferol, and rutin are common flavonoids in coffee cherry skin. Both classes (phenolic acids and flavonoids) have proven anticancerogenic, anti-inflammatory, and antibacterial (Dalar et al., 2018; Hu et al., 2019; Król et al., 2020). In Eastern European countries coffee could be considered as the main source of polyphenols. In Northern and Eastern European countries, fruits and vegetables are consumed significantly less than in Mediterranean countries. Interestingly, in the Northern and Eastern European countries, total polyphenol intake was found to be higher than in Mediterranean countries (Zamora-Ros et al., 2018). A prospective cohort study data confirmed a positive correlation between coffee consumption and decreased risk of all-cause mortality in Eastern European countries (Grosso et al., 2016).

During the roasting process, non-volatile compounds degrade and form new compounds with potential aroma and flavour attributes. The pleasant acidity is a key factor for sensory quality of coffee (Figueiredo et al., 2015), but increased organic acid concentration for some people can stimulate gastroesophageal reflux. The reflux can cause symptoms like heartburn, dysphagia, or pain in the chest. It is suggested to avoid coffee drinking or choose coffee with lower organic acid and caffeine content (Zaman et al., 2019; Wei et al., 2019). The roasting process can create some unwanted compounds and decrease the phenolic compound concentration. For example, Maillard reaction between amino acids and sugars can create pyrazines and pyrroles with positive aroma/flavour characteristics. Also, acrylamide can be formed as by-product of Maillard reaction. Acrylamide consumed in high amounts starts to work as a neu- 
rotoxin, and its concentration decreases with roast level of coffee (Bagdonaite et al., 2008; Koszucka et al., 2019). It is important to understand the positive and negative effects of roasting on bioactive compound composition and sensory quality of coffee. The aim of this study was to evaluate differences in chemical composition depending on roast level of coffee samples from Colombia.

\section{MATERIALS AND METHODS}

Coffee samples. Green Coffea arabica L. (Cattura/ Bourbon variety) beans from Caldas-Chinchina, Colombia were used in this study. The samples originated from Finca La Cristalina farm, with an elevation of 1650 meters above sea level. The post-harvesting method used was natural. By Specialty Coffee Association (SCA) standards and protocols, this coffee qualifies as a specialty with 89.0 points.

Roasting process. Green coffee was roasted in a local roastery in Latvia at three different roast levels using a Diedrich IR - 2.5 roaster (Diedrich Roasters, Ponderay, ID, USA) (Table 1). Each roasting batch size was $2.2 \mathrm{~kg}$. Roasting parameters are described in Table 1.

The roasted coffee beans were degassed in a dry, cool place for one week and then sealed in vacuum bags. All roasted samples were analysed within two to three weeks after roasting.

Coffee sample preparation for analyses of physical and chemical parameters. Roasted coffee beans were sealed in new $200 \mathrm{~g}$ vacuumed bags for the analysis of proteinogenic amino acids, fatty acids profile, and acrylamide.

Roasted coffee beans were ground in a KG79 Coffee grinder (DeLonghi, Italy) to fine grind size. Ground coffee samples were prepared immediately before analysis of moisture content and volatile compound profile. Samples were prepared and analysed in triplicate.

The roasted coffee beans were ground in a KG79 Coffee grinder (DeLonghi, Italy) to coarse grind level 20 minutes before the brewing process. The French Press brewing technique was used according to the Specialty Coffee Association guidelines (Specialty Coffe Association, 2016). The brewed coffee samples were prepared immediately before analysis of $\mathrm{pH}$, total phenol content (TPC), total flavonoid content (TF) and individual phenols. Samples were prepared and analysed in triplicate.
Physical parameter analysis. The moisture content was determined by the following standards: ISO 6673:2003 (green coffee beans); ISO 11294:1994 (roasted coffee beans).

pH analysis. The $\mathrm{pH}$ was determined after cooling the coffee brew to room temperature and measured with a "Jenway" 351101" pH meter (Jenway ${ }^{\mathrm{TM}}$, UK).

Proteinogenic amino acid, fatty acid profile, acrylamide content analyses. Roasted coffee beans were shipped to the Hamilton laboratory (Poland) for further analysis. Standard methods were used to assess the proteinogenic amino acids profile (PB-53/HPLC ed. II of 30.12.2008), fatty acids profile (PN-EN ISO 12966-1:2015-01, PN-EN ISO 12966-2:2017-05; except p.5.3 and 5.5, PN-EN ISO 12966-4:2015-07) and acrylamide concentration (PB-39/GC ed. IV of 12.01.2018).

Volatile compound profile analysis. The volatile compound profile was determined by Gloess et al. (2013) and Steen et al. (2017) methods with midifications. Compounds were extracted by solid phase microextraction (SPME) using carboxen/ polydimethylsiloxane (CAR/PDMS) fibre (Supelco, USA). The diluted coffee brew samples $(5 \mathrm{ml})$ were transferred to a $20 \mathrm{ml}$ glass vial. Extraction parameters were: extraction temperature $+50 \pm 2{ }^{\circ} \mathrm{C}$; incubation time 4 minutes; and extraction time 7 minutes. Injection parameters were: desorption time 15 minutes and temperature $+250{ }^{\circ} \mathrm{C}$. For gas chromatography, a "Perkin Elmer Clarus $500 "$ chromatograph with a mass spectrometer and "Elite-Wax ETR column" (60 mx 0,25mm internal diameter; DF 0.25 ) were used. A flow rate of $1 \mathrm{ml} \mathrm{min-1} \mathrm{was}$ held using helium as the carrier gas. The compounds were identified using the mass spectral database "Nist98".

Individual phenol analysis. Individual phenols in brewed coffee samples were analysed using high-performance liquid chromatography (HPLC) as described by Augšpole et al. (2018). The HPLC analysis was performed using a "LC-20 Prominence" chromatograph (Shimadzu USA Manufacturing Inc., USA) with a "Perkin Elmer C18" column $(4.6 \mathrm{~mm},-250 \mathrm{~mm}, 5 \mu \mathrm{m})$. The diode array detector gradient system (PDA-SPD-M10A) and column were maintained at $+30{ }^{\circ} \mathrm{C}$. The mobile phase consisted of methanol (A, 20\%), water (B, 78.4\%) and acetic acid (C, 1.6\%). Starting flow rate was $1 \mathrm{ml} \mathrm{min}{ }^{-1}$. The retention times of samples were compared with standards to determine the individual phenolic compounds in coffee samples.

Table 1. Coffee sample roasting parameters and moisture content

\begin{tabular}{ll|cc|c|c}
\hline \multicolumn{1}{c}{ Parameters } & & Green coffee & Light roast & Medium roast & Dark roast \\
\hline Roast temperature, ${ }^{\circ} \mathrm{C}$ & & - & 195 & 200 & 210 \\
Roast time, min. & & - & 10 & 11 & 12 \\
Colour parameters & $\mathrm{L}^{*}$ & - & $37.01 \pm 0.02$ & $33.94 \pm 0.03$ & $27.67 \pm 0.02$ \\
& $\mathrm{a}^{*}$ & - & $4.90 \pm 0.04$ & $8.57 \pm 0.05$ & $5.4 \pm 0.05$ \\
& $\mathrm{~b}^{*}$ & - & $5.05 \pm 0.01$ & $6.16 \pm 0.01$ & $4.04 \pm 0.01$ \\
Moisture content, \% & & $10.7 \pm 0$ & $3.0 \pm 0$ & $2.2 \pm 0$ & $2.0 \pm 0$
\end{tabular}

Colour was measured in CIE L*a*b* colour system using colorimeter (ColorTec-PCM, USA). 
Total phenol content (TPC). TPC was determined according to the spectrophotometric method using Folin-Ciocalteu reagent (Singleton et al., 1999) with gallic acid as a standard. Folin-Ciocalteu reagent (Sigma-Aldrich Chemie, Steinheim, Germany) (diluted in a ratio 1:10 with distilled water) was added $(2.5 \mathrm{ml})$ to diluted coffee extract $(0.5$ $\mathrm{mL})$. After 5 minutes, $7.5 \% \mathrm{Na}_{2} \mathrm{CO}_{3}$ solution $(2.0 \mathrm{ml})$ was added. After 30 minutes, the absorbance of samples was measured at $\lambda=765 \mathrm{~nm}$ using a Jenway 6300 spectrophotometer (Barloworld Scientific Ltd., UK) as described by Laukaleja and Kruma (2019). The total phenolic concentration was expressed as gallic acid equivalents per $100 \mathrm{ml}$ of brewed coffee (mg GAE $100 \mathrm{ml}^{-1}$ ).

Total flavonoid concentration (TFC). TFC was determined using spectrophotometry as reported by Niseteo et al. (2012) with some modifications. Briefly, diluted coffee extract $(0.5 \mathrm{ml})$ was added to distilled $(2.0 \mathrm{ml})$ water, and then $5 \% \mathrm{NaNO}_{2}$ solution $(0.15 \mathrm{ml})$ was added. After 5 minutes, $10 \% \mathrm{AlCl}_{3} * 6 \mathrm{H}_{2} \mathrm{O}$ solution $(0.15 \mathrm{ml})$ was added. After 5 minutes, $1 \mathrm{M} \mathrm{NaOH}$ solution $(1.0 \mathrm{ml})$ was added, and the flask was mixed. After 15 min of incubation at room temperature, the absorbance of samples was measured at $\lambda=$ $415 \mathrm{~nm}$ with a Jenway 6300 spectrophotometer (Barloworld Scientific Ltd., UK) (Laukaleja and Kruma, 2019). Total flavonoid concentration was expressed as catechin equivalents (CE) per $100 \mathrm{ml}$ of brewed coffee $\left(\mathrm{mg} \mathrm{CE} \cdot 100 \mathrm{ml}^{-1}\right)$.

Statistical analysis. The data were reported as means with standard deviations (SD). One-way ANOVA was carried out to determine significant differences in chemical parameters among coffee samples. Significant differences were determined at $p \leq 0.05$. The data were analysed with Microsoft Office Excel 2013. A Principal Components Analysis (PCA) correlation biplot PCA was produced using XLSTAT software (vs. 2020.2.3.65347, XLSTAT, New York, NY, USA).

\section{RESULTS}

Moisture content and $\mathbf{p H}$. Moisture content ranged from $10.7 \%$ in green coffee and rapidly decreased to $3.0 \%$ in light roasted coffee, to $2.2 \%$ in medium roasted, and to $2.0 \%$ in dark roasted coffee (Table 1). The $\mathrm{pH}$ was the highest in green coffee $(\mathrm{pH}=5.58)$ and decreased to $\mathrm{pH} 5.0$ in light roasted coffee, then again increased from $\mathrm{pH} 5.17$ in the medium roasted to $\mathrm{pH} 5.31$ in the dark roasted coffee (Table 1).

Amino acid and fatty acid profile. Among 17 amino acids, 13 showed the highest concentration in medium roasted coffee (Table 2). Only serine and cysteine concentration decreased with increased roast level. At all roast levels glutamic acid had the highest concentration. No association between roast level and amino acid concentration were found by Fisher's exact test. However, strong correlation was observed between several amino acids. Arginine had strong correlation with cysteine $(r=0.999 ; p<0.05)$, and glutamic acid with glycine $(r=1.000 ; p<0.05)$. Leucine had strong correlation with alanine, tyrosine, valine, methionine, isoleucine, and phenylalanine $(r=0.998 ; p<$
Table 2. Amino acid content in different roast level coffee, g.100 $\mathrm{g}^{-1}$

\begin{tabular}{l|c|c|c|c}
\hline \multicolumn{1}{c|}{ Amino acids } & $\begin{array}{c}\text { Green } \\
\text { coffee }\end{array}$ & $\begin{array}{c}\text { Light } \\
\text { roast }\end{array}$ & $\begin{array}{c}\text { Medium } \\
\text { roast }\end{array}$ & $\begin{array}{c}\text { Dark } \\
\text { roast }\end{array}$ \\
\hline Aspartic acid & $0.85 \mathrm{a}$ & $0.68 \mathrm{c}$ & $0.75 \mathrm{~b}$ & $0.69 \mathrm{c}$ \\
Glutamic acid & $1.99 \mathrm{~b}$ & $1.84 \mathrm{c}$ & $2.15 \mathrm{a}$ & $2.11 \mathrm{a}$ \\
Serine & $0.52 \mathrm{a}$ & $0.31 \mathrm{~b}$ & $0.3 \mathrm{~b}$ & $0.2 \mathrm{c}$ \\
Glycine & $0.65 \mathrm{ab}$ & $0.58 \mathrm{~b}$ & $0.68 \mathrm{a}$ & $0.67 \mathrm{a}$ \\
Histidine & $0.22 \mathrm{a}$ & 0.17 & 0.19 & 0.18 \\
Arginine & $0.6 \mathrm{a}$ & $0.1 \mathrm{~b}$ & $0.08 \mathrm{c}$ & $0.057 \mathrm{~d}$ \\
Threonine & $0.61 \mathrm{a}$ & $0.53 \mathrm{a}$ & $0.59 \mathrm{a}$ & $0.55 \mathrm{a}$ \\
Alanine & $0.46 \mathrm{a}$ & $0.43 \mathrm{a}$ & $0.51 \mathrm{a}$ & $0.51 \mathrm{a}$ \\
Proline & $0.57 \mathrm{~b}$ & $0.51 \mathrm{bc}$ & $0.59 \mathrm{ab}$ & $0.61 \mathrm{a}$ \\
Tyrosine & $0.32 \mathrm{a}$ & $0.28 \mathrm{a}$ & $0.33 \mathrm{a}$ & $0.33 \mathrm{a}$ \\
Valine & $0.52 \mathrm{ab}$ & $0.47 \mathrm{c}$ & $0.53 \mathrm{a}$ & $0.53 \mathrm{a}$ \\
Methionine & $0.14 \mathrm{a}$ & $0.14 \mathrm{a}$ & $0.15 \mathrm{a}$ & $0.15 \mathrm{a}$ \\
Cysteine & $0.15 \mathrm{~d}$ & $0.062 \mathrm{a}$ & $0.045 \mathrm{~b}$ & $0.028 \mathrm{c}$ \\
Isoleucine & $0.34 \mathrm{a}$ & $0.31 \mathrm{a}$ & $0.35 \mathrm{a}$ & $0.35 \mathrm{a}$ \\
Leucine & $0.85 \mathrm{~b}$ & $0.78 \mathrm{c}$ & $0.91 \mathrm{a}$ & $0.92 \mathrm{a}$ \\
Phenylalanine & $0.52 \mathrm{ab}$ & $0.47 \mathrm{~b}$ & $0.55 \mathrm{a}$ & $0.55 \mathrm{a}$ \\
Lysine & $0.58 \mathrm{a}$ & $0.078 \mathrm{c}$ & $0.086 \mathrm{~b}$ & $0.077 \mathrm{c}$
\end{tabular}

Different letters $(a, b, c)$ within a row indicate the statistically significant difference between coffee samples $(p<0.05)$.

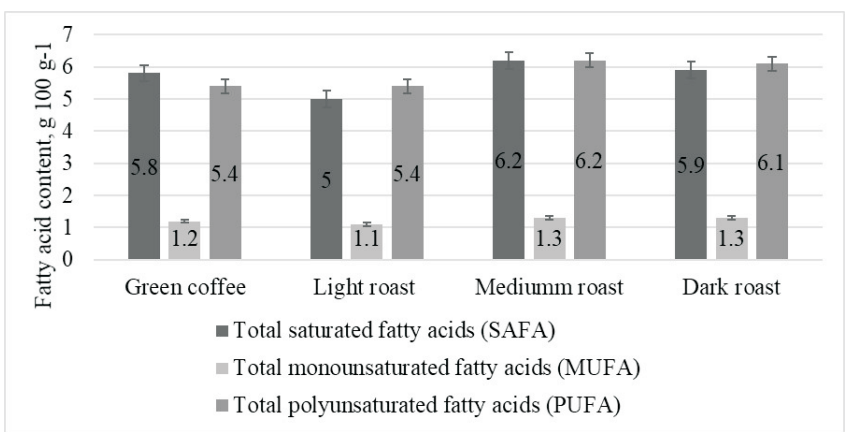

Fig. 1. Fatty acid concentration in different roast level coffee.

0.05). Strong correlation was also detected between alanine, tyrosine, valine, methionine, isoleucine, and phenylalanine $(r=1.000 ; p<0.05)$.

Total saturated fatty acid (SAFA), total monounsaturated fatty acid (MUFA), and total polyunsaturated fatty acid (PUFA) concentrations were the highest in medium roast and the lowest in the light roasted coffee (Fig. 1).

Volatile compound profile. Forty-one compounds from eight chemical classes were detected in all roast levels. Furan compounds in all roast levels had the highest peak area mean percentage, compared to other chemical classes (Table 3). Light roasted coffee had the highest aldehyde, organic acid, and alcohol concentration, while medium roasted coffee had the highest pyrazine and furan concentration, and dark roasted coffee - the highest terpene, phenolic acid, and ketone concentration.

Acrylamide concentration. In light roasted coffee, the acrylamide concentration was $290 \mu \mathrm{g} \cdot 100 \mathrm{~g}^{-1}$ (Fig. 2). However, acrylamide concentration was highest in medium 
Table 3. Sum of volatile compound peak areas per chemical class in coffee beans of different roast levels

\begin{tabular}{l|cccc}
\hline \multirow{2}{*}{ Chemical classes } & \multicolumn{3}{|c}{ Sum of peak areas, \% } \\
\cline { 2 - 4 } & light roast & medium roast & dark roast \\
\hline Aldehydes & $12.97 \mathrm{a}$ & $6.46 \mathrm{c}$ & $9.89 \mathrm{~b}$ \\
Organic acids & $21.12 \mathrm{a}$ & $7.63 \mathrm{c}$ & $10.3 \mathrm{~b}$ \\
Alcohols & 1.68 & - & - \\
Terpenes & $1.22 \mathrm{~b}$ & $0.79 \mathrm{c}$ & $27.80 \mathrm{a}$ \\
Phenolic acids & $0.65 \mathrm{~b}$ & $0.57 \mathrm{c}$ & $1.63 \mathrm{a}$ \\
Ketones & $10.23 \mathrm{~b}$ & $5.49 \mathrm{c}$ & $10.94 \mathrm{a}$ \\
Furans & $29.59 \mathrm{~b}$ & $51.75 \mathrm{a}$ & $28.22 \mathrm{~b}$ \\
Pyrazines & $22.53 \mathrm{~b}$ & $27.32 \mathrm{a}$ & $11.21 \mathrm{c}$ \\
\hline
\end{tabular}

Different letters $(a, b, c)$ within a row indicate the statistically significant difference between coffee samples $(p<0.05)$.

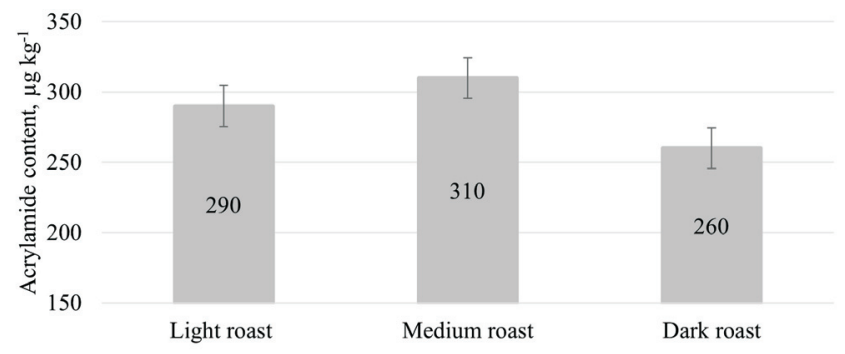

Fig. 2. Acrylamide concentration in different roast level coffee.

roasted coffee $\left(310 \mu \mathrm{g} \cdot 100 \mathrm{~g}^{-1}\right)$ and then rapidly decreased in dark roasted coffee $\left(260 \mu \mathrm{g} \cdot 100 \mathrm{~g}^{-1}\right)$.

Total phenolic, flavonoid, and individual phenol compound concentration. The highest total phenolic and flavonoid concentration was found in light roasted coffee

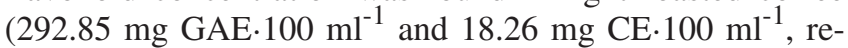
spectively) and the lowest in dark roasted coffee (246.17 $\mathrm{mg} \mathrm{GAE} \cdot \mathrm{ml}^{-1} ; 15.79 \mathrm{mg} \mathrm{CE} \cdot \mathrm{ml}^{-1}$ ) (Table 4). From 14 phenolic compounds that were detected, nine were phenolic acids (2-hydroxycinnamic acid, 3.5-dihydroxybenzoic acid, 4-hydroxybenzoic acid, caffeic acid, chlorogenic acid,
Table 4. Total phenolic and flavonoid concentration in different roast level coffee brews*

\begin{tabular}{cc|c|c}
\hline Compound & Light roast & Medium roast & Dark roast \\
\hline TPC, mg GAE $100 \mathrm{ml}^{-1}$ & $292.85 \pm 0.05$ & $265.30 \pm 0.03$ & $246.17 \pm 0.03$ \\
TFC, mg CE $100 \mathrm{ml}^{-1}$ & $18.26 \pm 0.05$ & $16.71 \pm 0.04$ & $14.79 \pm 0.03$
\end{tabular}

*Data expressed as means \pm standard deviations (SDs)

ferulic acid, gallic acid, p-coumaric acid, and sinapic acid) and five were flavonoids (catechin hydrate, epicatechin, luteolin, rutin, and vanillin) (Table 5). The highest concentration, irrespective of the roast level, occurred for 3.5-dihydroxybenzoic acid and chlorogenic acid, although their concentration decreased most rapidly with roasting. For example, the chlorogenic acid concentration decreased from $117.54 \mathrm{mg} \cdot \mathrm{ml}^{-1}$ in light roasted coffee to $53.0 \mathrm{mg} \cdot \mathrm{ml}^{-1}$ in dark roasted coffee. Only sinapic and 4-hydroxybenzoic acid increased with the increased roast level.

PCA plot. Principal Component Analysis (PCA) was used to visualise the roasting effect on the chemical compound profile (Fig. 3). The first Principal Component represents effect of the roast level on chemical compound composition. The second component separated the samples based on the amino acid concentration in medium roasted. Light roasted coffee showed a positive association with most phenolic compounds and a negative association with fatty acid concentration. Medium roasted coffee had strong association with aspartic, lysine, and acrylamide concentration.

\section{DISCUSSION}

Moisture content and pH. Moisture content in the sampled green coffee beans was similar to that reported in other studies, under $11 \%$, which is suggested to maintain the quality standards for specialty coffee (Borém et al., 2016; Tolessa et al., 2016). Some studies have linked moisture content with $\mathrm{pH}$ in coffee (Lee et al., 2017).The pH level

Table 5. Means of individual phenol compound concentration in different roast level coffee brews

\begin{tabular}{|c|c|c|c|}
\hline \multirow[t]{2}{*}{ Coffee sample } & \multicolumn{3}{|c|}{ Means of concentration \pm standard deviations, $\mathrm{mg} \cdot 100 \mathrm{ml}^{-1}$} \\
\hline & light roast & medium roast & dark roast \\
\hline Gallic acid & $0.02 \pm 0.03 b$ & $0.07 \pm 0 \mathrm{a}$ & $0.07 \pm 0 \mathrm{a}$ \\
\hline 3,5-Dihydroxybenzoic acid & $217.24 \pm 0.96 a$ & $182.68 \pm 0.63 b$ & $114.81 \pm 0.45 c$ \\
\hline Catechin hydrate & $2.54 \pm 0.19 \mathrm{a}$ & $2.62 \pm 0.10 \mathrm{a}$ & $1.91 \pm 0.14 b$ \\
\hline 4-Hydroxybenzoic acid & $1.95 \pm 0.04 \mathrm{c}$ & $2.92 \pm 0.02 b$ & $3.66 \pm 0.08 \mathrm{a}$ \\
\hline Caffeic acid & $1.34 \pm 0.88 \mathrm{c}$ & $2.14 \pm 0.09 \mathrm{a}$ & $1.82 \pm 0 b$ \\
\hline Epicatechin & $0.19 \pm 0$ & - & - \\
\hline Vanillin & $0.18 \pm 0.03 a$ & $0.15 \pm 0 b$ & $0.08 \pm 0 b$ \\
\hline p-Coumaric acid & $0.04 \pm 0.01 \mathrm{a}$ & $0.01 \pm 0 b$ & $0.01 \pm 0 b$ \\
\hline Sinapic acid & $0.85 \pm 1.21 b$ & $2.07 \pm 0.02 \mathrm{ab}$ & $2.46 \pm 0.01 \mathrm{a}$ \\
\hline Ferulic acid & $0.05 \pm 0 b$ & $0.06 \pm 0 \mathrm{a}$ & $0.06 \pm 0 \mathrm{a}$ \\
\hline Rutin & $9.70 \pm 0.32 \mathrm{a}$ & $7.40 \pm 0.22 b$ & $3.37 \pm 0.31 \mathrm{c}$ \\
\hline Luteolin & $0.72 \pm 0.50 \mathrm{a}$ & $0.36 \pm 0 b$ & $0.34 \pm 0.01 b$ \\
\hline
\end{tabular}

Different letters $(\mathrm{a}, \mathrm{b}, \mathrm{c})$ within a row indicate the statistically significant difference between coffee samples $(p<0.05)$. 


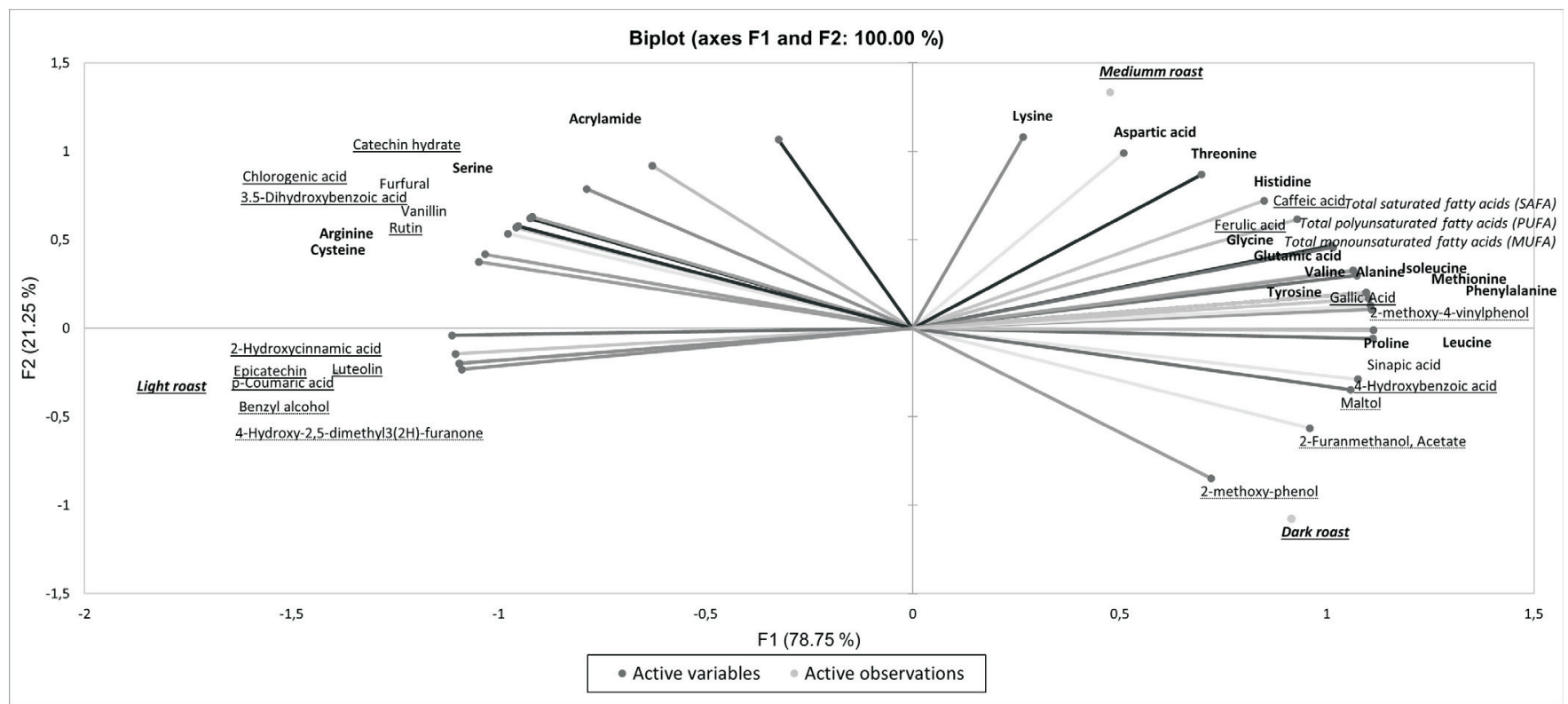

Fig. 3. Principal Component Analysis of chemical composition in different roast level coffee (variables in bold - amino acids; variables in Italic - fatty acids; variables with underline - individual phenolic compounds; variables with dotted underline - important volatile compounds.

increased with increased roast level in a study by Rao et al. (2020). Previous studies also support that $\mathrm{pH}$ level is determined by aliphatic acid formation from carbohydrate degradation during roasting. For example, formic acid and acetic acid are associated with a lower $\mathrm{pH}$ level in light roasted coffee (Ginz et al., 2000; Borém et al., 2016; Rao, Fuller and Grim, 2020).

Amino acid and fatty acid profile. Level of roasting did not show direct association with the amino acid profile. In line with previous studies, glutamic and aspartic acids are the dominant amino acids in roasted coffee (Bressanello et al., 2017). However, the present study did not confirm previously reported rapid degradation of amino acids with increased roasting level (Guenther et al., 2007; Wei et al., 2017). Only arginine and serine showed large decrease in concentration during roasting, as reported previously (Moreira et al., 2012). The changes of fatty acid profile are in line with previous studies. The higher fatty acid content in medium roasted coffee can be explained by lipid degradation (Lee et al., 2017). The lipid degradation suggests the fatty acid concentration would be higher in dark roasted coffee, but this was not detected in our study. A possible explanation is that phenolic compound inhibited lipid oxidation (Hu et al., 2019).

Total and individual phenol, flavonoid content. The degradation of phenolic acid and flavonoid compounds with increasing roast level explains the decrease of total phenol and flavonoid concentration. Chlorogenic and 3.5-dihydroxybenzoic acids have been reported as the most abundant phenolic compounds in coffee. These two compounds are suggested to be responsible for melanoidin formation (Moreira et al., 2012; Coelho et al., 2014). However, only chlorogenic acid has been associated with potential antioxidative activity in coffee, even if the 3.5-dihydroxybenzoic acid concentration is higher (Alcalde et al., 2019).
Chlorogenic acid thermal degradation can result in formation of other compounds with potential antioxidative activity, one of which is caffeic acid (Kamiyama et al., 2015) and this study results confirmed that caffeic acid concentration increased with roast level. Another possible reason for rapid degradation of chlorogenic acid at a light roast level is its transformation into chlorogenic acid lactones (Farah et al., 2005). Budryn et al. (2015) observed that chlorogenic acid starts to degrade to chlorogenic acid lactones rapidly when the roasting temperature is above $203{ }^{\circ} \mathrm{C}$.

Volatile compound profile. The high proportion of furan compounds compared to other chemical classes can be explained by their formation from carbohydrate and amino acid degradation at first, but with longer roast period furans from polysaturated acid oxidation (Petisca et al., 2012; Gruczyńska et al., 2018; Cordoba et al., 2019). The increase of the volatile phenolic compound concentration is associated with phenolic compound degradation. For example, caffeic acid degradation in dark roasted coffee results in formation of volatile phenols such as 2-methoxy-4 vinylphenol. In the PCA plot, dark roasted coffee had positive association with 2-methoxy-4-vinylphenol and 2-methoxyphenol (Kamiyama et al., 2015). These phenolic volatile compounds are associated with a smoky, spicy, and even burnt aroma (Brattoli et al., 2013; Poltronieri and Rossi, 2016). Similar to phenolic acids, volatile organic acid concentration decreased with increased roast level, because of thermal instability. Organic acids such as acetic and formic acids are formed in roasting from carbohydrates. Ginz et al. (2000) reported that organic acids start to degrade at a medium roast level (above $240{ }^{\circ} \mathrm{C}$ ), but in that study roasting occurred for only three minutes. The negative correlation between phenolic and volatile organic acid concentration confirmed the $\mathrm{pH}$ increases with the roast level. Therefore, dark roasted coffee could be more tolerable for coffee consumers with gastro esophageal reflux symptoms. However, 
these consumers should be aware of the caffeine concentration also (Wei et al., 2019; Zaman et al., 2019). The PCA plot shows association of light roasted coffee with volatile compounds like benzyl alcohol and 4-hydroxy-2,5dimethyl-3(2H)-furanone, which are associated with fruity, floral and caramel taste in other studies as well as with positive impact on coffee aroma quality (Toledo et al., 2016; Pereira et al., 2019).

Acrylamide content. Acrylamide formation often is associated with the Maillard reaction (reaction between reducing carbohydrates and asparagine). However, there was no association found between aspartic acid (asparagine) and acrylamide content in coffee in the present study. Some studies indicated that acrylamide could be formed through amino-dehydroxylation, or through pyrolytic reactions (which involves serine and cysteine) by converting pyruvic acid to lactic acid and generation of acrylamide (if ammonia is present) (Guenther et al., 2007; Bagdonaite et al., 2008). This might explain the results of our study, because the decrease of serine and cysteine concentration at a light roast level could be explained by their involvement in acrylamide formation. Scientific opinions vary about the peak point of acrylamide concentration decrease. Bagdonaite and Murkovic (2004) observed the highest acrylamide concentration after the first five minutes of roasting, both at 220 and $240{ }^{\circ} \mathrm{C}$. In contrast, Bertuzzi et al. (2020) reported the acrylamide peak level after 10 minutes of roasting at $175-177^{\circ} \mathrm{C}$ and rapid decrease after 14 minutes of roasting at $203-205{ }^{\circ} \mathrm{C}$. In our study, the acrylamide content was lower than Regulation (EC) No. 852/2004 Benchmark levels for the presence of acrylamide in roasted coffee (400 $\mu \mathrm{g} \cdot \mathrm{kg}^{-1}$ ) (Commission Regulation (EU) 2017/2158). The coffee brewing method can also influence the acrylamide extraction. Bagdonaite and Murkovic (2004) and Michalak et al. (2020) reported that extraction time and grind size have the strongest correlation with acrylamide concentration in the brew.

\section{CONCLUSIONS}

The highest total and individual phenolic and flavonoid concentration was found in light roasted coffee $(291.85 \mathrm{mg}$ $\mathrm{GAE} \cdot \mathrm{ml}^{-1} ; 18.26 \mathrm{mg} \mathrm{CE} \cdot \mathrm{ml}^{-1}$ ) and it decreased with increased roast level. From a volatile compound point of view, the light roasted coffee had higher concentration of volatiles associated with fruity, creamy, and caramelised aroma, flavour characteristics, while the dark roasted coffee had higher concentration of volatiles, such as phenolic acids, which are associated with smoky, burnt aroma, flavour characteristics. Dark roasted coffee had the lowest acrylamide concentration, organic acid content, and the highest $\mathrm{pH}$ in coffee brew, which would be more suitable for coffee consumers with gastro esophageal reflux symptoms.

\section{ACKNOWLEDGEMENTS}

The present research has been partly funded by the programme "Strengthening Research Capacity in the Lat- via University of Life Sciences and Technologies" project "The changes of biologically active compounds of Specialty coffee under the influence of technological processes" (Z22) and partly funded by the doctoral studies grant "Transition to the new doctoral funding model at the Latvia University of Life Sciences and Technologies" (Contract No. 8.2.2.0/20/I/001). The authors gratefully acknowledge Kalve Coffee Roasters for providing coffee samples and supporting the research.

\section{REFERENCES}

Akiyama, M., Murakami, K., Ikeda, M., Iwatsuki, K., Wada, A., Tokuno, K., Onishi, M., Iwabuchi, H. (2007). Analysis of the headspace volatiles of freshly brewed arabica coffee using solid-phase microextraction. Food Chem. Toxicol., 72 (7), 388-396.

Alcalde, B., Granados, M., Saurina, J. (2019). Exploring the antioxidant features of polyphenols by spectroscopic and electrochemical methods. Antioxidants, 8 (11), 523.

Augšpole, I., Dūma, M., Cinkmanis, I., Ozola, B. (2018). Herbal teas as a rich source of phenolic compounds. Chemija, 29 (4), 257-262.

Bagdonaite, K., Derler, K., Murkovic, M. (2008). Determination of acrylamide during roasting of coffee. J. Agric. Food Chem., 56 (15), 6081-6086.

Bagdonaite, K., Murkovic, M. (2004). Factors affecting the formation of acrylamide in coffee. Czech J. Food Sci., 22, 22-24.

Bertuzzi, T., Martinelli, E., Mulazzi, A., Rastelli, S. (2020). Acrylamide determination during an industrial roasting process of coffee and the influence of asparagine and low molecular weight sugars. Food Chem., 303, 125372.

Borém, F. M., Figueiredo, L. P., Ribeiro, F. C., Taveira, J. H. S., Giomo, G. S., Salva, T. J. G. (2016). The relationship between organic acids, sucrose and the quality of specialty coffees. African J. Agric. Res., 11 (8), 709-717.

Brattoli, M., Cisternino, E., Dambruoso, P. R., Gennaro, G. de (2013). Gas chromatography analysis with olfactometric detection (GC-O) as a useful methodology for chemical characterization of odorous compounds. Sensors, 13, 16759-16800.

Bressanello, D., Liberto, E., Cordero, C., Rubiolo, P., Pellegrino, G., Ruosi, M. R., Bicchi, C. (2017). Coffee aroma: Chemometric comparison of the chemical information provided by three different samplings combined with GC-MS to describe the sensory properties in cup. Food Chem., 214 (Supplement C), 218-226.

Budryn, G., Nebesny, E., Oracz, J. (2015). Correlation between the stability of chlorogenic acids, antioxidant activity and acrylamide content in coffee beans roasted in different conditions. Int. J. Food Prop., 18 (2), 290-302.

Coelho, C., Ribeiro, M., Cruz, A. C. S., Domingues, M. R. M., Coimbra, M. A., Bunzel, M., Nunes, F. M. (2014). Nature of phenolic compounds in coffee melanoidins. J. Agric. Food Chem., 62 (31), 7843-7853.

Cascro, N. C., Pataquiva, L., Osorio, C., Moreno, F. L. M., Ruiz, R. Y. (2019). Effect of grinding, extraction time and type of coffee on the physicochemical and flavour characteristics of cold brew coffee. Sci. Rep., 9 (1), 1-12.

Dalar, A., Dogan, A., Bengu, A.S., Mukemre, M., Celik, I. (2018). Screening in vivo antioxidant and haematological properties of sumac and acorn bioactive rich extracts. Ind. Crops Prod., 124, 20-27.

Farah, A., Paulis, T., Trugo, L. C., Martin, P. R. (2005). Effect of roasting on the formation of chlorogenic acid lactones in coffee. J. Agric. Food Chem., 53 (5), 1505-1513.

Figueiredo, L. P., Borem, F. M., Ribeiro, F. C., Giomo, G. S., Taveira, J. H. S. T., Malta, M. R. (2015). Fatty acid profiles and parameters of quality of specialty coffees produced in different Brazilian regions. African J. Agric. Res., 10 (35), 3484-3493. 
Ginz, M., Balzer, H. H., Bradbury, A. G. W., Maier, H. G. (2000). Formation of aliphatic acids by carbohydrate degradation during roasting of coffee. Eur. Food Res. Technol., 211 (6), 404-410.

Gloess, A. N., Schönbächler, B., Klopprogge, B., D’Ambrosio, L., Chatelain, K., Bongartz, A., Strittmatter, A., Rast, M., Yeretzian, C. (2013). Comparison of nine common coffee extraction methods: Instrumental and sensory analysis. Eur. Food Res. Technol., 236 (4), 607-627.

Grosso, G., Stepaniak, U., Micek, A., Ste, D., Bobak, M., Pajak, A. (2016). Coffee consumption and mortality in three Eastern European countries: Results from the HAPIEE (Health, Alcohol and Psychosocial factors in Eastern Europe ) study. Public Health Nutr., 20 (1), 82-91.

Gruczyńska, E., Kowalska, D., Kozłowska, M., Majewska, E., Tarnowska, K. (2018). Furan in roasted, ground and brewed coffee. Rocz. Panstw. Zakl. Hig., 69 (2), 111-118.

Guenther, H., Anklam, E., Wenzl, T., Stadler, R. H. (2007). Acrylamide in coffee: Review of progress in analysis, formation and level reduction. Food Addit. Contam., 24 (S1), 60-70.

Hu, G. L., Wang, X., Zhang, L., Qiu, M. H. (2019). The sources and mechanisms of bioactive ingredients in coffee. Food Funct., 10 (6), 3113-3126.

Kamiyama, M., Moon, J. K., Jang, H. W., Shibamoto, T. (2015). Role of degradation products of chlorogenic acid in the antioxidant activity of roasted coffee. J. Agric. Food Chem., 63 (7), 1996-2005.

Koszucka, A., Nowak, A., Nowak, I., Motyl, I. (2019). Acrylamide in human diet, its metabolism, toxicity, inactivation and the associated European Union legal regulations in food industry. Crit. Rev. Food Sci. Nutr., 60 (10), 1677-1692.

Król, K., Gantner, M., Tatarak, A., Hallmann, E. (2020). The content of polyphenols in coffee beans as roasting, origin and storage effect. Eur. Food Res. Technol., 246 (1), 33-39.

Lee, A., Lim, W., Kim, S., Khil, H., Cheon, E., An, S., Hong, S. E., Lee, D. H., Kang, S.-S., Oh, H., Keum, N. N., Hsieh, C.-C. (2019). Coffee intake and obesity: A meta-analysis. Nutrients, 11 (6), 1274.

Lee, S. J., Kim, M. K., Lee, K. G. (2017). Effect of reversed coffee grinding and roasting process on physicochemical properties including volatile compound profiles. Innov. Food Sci. Emerg. Technol., 44 (October 2016), 97-102.

Michalak, J., Czarnowska-Kujawska, M., Gujska, E., Klepacka, J., Tońska, E. (2020). Effect of the brewing process on the acrylamide content in coffee beverages. In: Proceedings Of The Nutrition Society, Vol. 79, Issue Oce2: $13^{\text {th }}$ European Nutrition Conference, Fens 2019, 15-18 October 2019, Malnutrition In An Obese World: European Perspectives. Cambridge University Press. E293

Moreira, A. S. P., Nunes, F. M., Domingues, M. R., Coimbra, M. A. (2012). Coffee melanoidins: Structures, mechanisms of formation and potential health impacts. Food Funct., 3 (9), 903.

Niseteo, T., Komes, D., Belščak-Cvitanović, A., Horžić, D., Budeč, M. (2012). Bioactive composition and antioxidant potential of different commonly consumed coffee brews affected by their preparation technique and milk addition. Food Chem., 134, 1870-1877.

Received 22 March 2021

Accepted in the final form 5 January 2022
Commission Regulation (EU) 2017/2158 (2017). Official Journal of the European Union,

https://eur-lex.europa.eu/legal-content/EN/TXT/PDF/?uri= CELEX:32017R2158\&from=DE (accessed 16.12.2020).

Pereira, E., Gilberto, V. D. M., Neto, D. P. D. C., Júnior, A. I. M., Vásquez, Z. S., Medeiros, A. B. P., Vandenberghe, L. P. S., Soccol, C. R. (2019). Exploring the impacts of postharvest processing on the aroma formation of coffee beans: A review. Food Chem., 272 (December 2017), 441-452.

Petisca, C., Pérez-Palacios, T., Farah, A., Pinho, O., Ferreira, I. M. P. L. V. O. (2012). Furans and other volatile compounds in ground roasted and espresso coffee using headspace solid-phase microextraction: Effect of roasting speed. Food Bioprod. Process., 91 (3), 233-241.

Poltronieri, P., Rossi, F. (2016). Challenges in specialty coffee processing and quality assurance. Challenges, 7 (19), 1-22.

Poole, R., Kennedy, O. J., Roderick, P., Fallowfield, J. A., Hayes, P. C., Parkes, J. (2017). Coffee consumption and health: Umbrella review of meta-analyses of multiple health outcomes. Brit. Med. J., 359, j5024.

Rao, N. Z., Fuller, M., Grim, M. D. (2020). Physiochemical characteristics of hot and cold brew coffee chemistry: The effects of roast level and brewing temperature on compound extraction. Foods, 9 (7), 1-12.

Singleton, V. L., Orthofer, R., Lamuela-Raventós, R. (1999). Analysis of total phenols and other oxidation substrates and antioxidants by means of folin-ciocalteu reagent. Methods Enzymol., 299 (1974), 152-178.

Specialty Coffee Association (2016). Guidelines for Brewing with a Three Cup French Press,

https://sca.coffee/s/best-practices-three-cup-french-press.pdf (accessed 14.12.2020).

Steen, I., Waehrens, S. S., Petersen, M. A., Münchow, M., Bredie, W. L. P. (2017). Influence of serving temperature on flavour perception and release of Bourbon Caturra coffee. Food Chem., 219, 61-68.

Toledo, P. R. A. B., Pezza, L., Pezza, H. R., Toci, A. T. (2016). Relationship between the different aspects related to coffee quality and their volatile compounds. Compr. Rev. Food Sci. Food Saf., 15 (4), 705-719.

Tolessa, K., Rademaker, M., De Baets, B., Boeckx, P. (2016). Prediction of specialty coffee cup quality based on near infrared spectra of green coffee beans, Talanta, 150, 367-374.

Wei, L., Yu, G., Wai, M., Curran, P., Yu, B. (2017). Modulation of the volatile and non-volatile profiles of coffee fermented with Yarrowia lipolytica?: II. Roasted coffee. LWT - Food Sci. Technol., 80, 32-42.

Wei, T. Y., Hsueh, P. H., Wen, S. H., Chen, C. L., Wang, C. C. (2019). The role of tea and coffee in the development of gastroesophageal reflux disease, Tzu Chi Med. J., 31 (3), 169-176.

Zaman, W. S. W. K., Loh, S.P., Mohd Esa, N. (2019). Coffee and gastrointestinal health: A review, Malaysian J. Med. Heal. Sci., 15 (SP1), 96-103.

Zamora-Ros, R., Knaze, V., Rothwell, J. A., Hemon, B., Moskal, A., Overvad, K., Tjønneland, A., Kyrø, C., Fagherazzi, G., Boutron-Ruault, M.-C. et al. (2018). Dietary polyphenol intake in Europe: The European Prospective Investigation into Cancer and Nutrition (EPIC) study. Eur. J. Nutr., 55 (4), 1359-1375.

\section{GRAUZDĒŠANAS PROCESA IETEKME UZ KOLUMBIJAS KAFIJAS ĶIIMISKO SASTĀVU}

Pētījuma mērḳis bija novērtēt ḳīmiskā sastāva izmaiṇas trīs dažāda grauzdējuma pakāpēs (gaiša, vidēja, tumša) kafijā no Kolombijas. Gaiša grauzdējuma kafijā tika konstatēts lielāks kopējo un atseviško fenolu, flavonoīdu saturs, kas samazinājās līdz ar grauzdēšanas pakāpes palielināšanos. Hlorogēnskābe un 3.5-dihidroksibenzoskābe uzrādīja proporcionāli lielāko koncentrāciju starp 14 atsevišķiem fenolu savienojumiem. Fenolu savienojumu noārdīšanās veidojusi gaistošos fenolus, kā 2-metoksifenols ar dūmakainu, deguma aromātu, kura koncentrācija attiecīgi bija lielāka tumša grauzdējuma kafijā. Gaiša grauzdējuma kafijā ir lielākais organisko skābju saturs un mazākais pH. Akrilamīda koncentrācija sasniedza augstāko vērtību vidēja grauzdējuma kafijā un strauji samazinājās tumša grauzdējuma kafijā. Nevienā no grauzdēšanas pakāpēm netika pārsniegta pieḷaujamā akrilamīda koncentrācija salīdzinājumā ar Eiropas Nekaitīguma iestādes noteikto references līmeni grauzdētā kafijā $\left(400 \mu \mathrm{g} \cdot \mathrm{kg}^{-1}\right)$. Cilvēkiem, kurus apmierina kafijas skābums, būtu ieteicama viegla grauzdējuma kafija, kurā arī ir lielākā fenolu savienojumu koncentrācija. Savukārt kafijas patērētājiem ar gastroezofageālā atviḷna simptomiem būtu ieteicams izvēlēties tumša grauzdējuma kafiju, kurā ir mazāks skābju saturs. 